\title{
Why does the United Kingdom now need a written constitution?
}

\author{
ANDREW BLICK \\ King's College London \\ AND \\ BRICE DICKSON \\ Queen's University Belfast
}

\begin{abstract}
Introduction
$\mathrm{T}$ he following exchange of views between Professor Andrew Blick of King's College London and Professor Brice Dickson of Queen's University Belfast was compiled over a four-month period between September 2019 and January 2020, a time of extreme constitutional tension in the UK. The exchange was prompted by the authors' initial difference of opinion over whether the UK should devise for itself a written constitution.
\end{abstract}

\begin{abstract}
AB: The contemporary political environment in the UK adds a new perspective to a preexisting argument. It involves whether the UK should adopt a text with a special legal status setting out the fundamental principles, rules and practices of the political system, that is, a 'written' constitution.

Advocates of the so-called 'unwritten' UK constitution often stress the merits of its supposed flexibility. In fact, the debate on this point is not one of rigidity versus flexibility but of considered change versus casual change. Recent events in the UK surrounding Brexit, whatever view one takes on the substantive matter, have revealed a substantial weakness in our constitution in this regard. The enormous constitutional changes necessitated by the implementation of the 'leave' result were treated as afterthoughts. They were devised after the vote. Under a written constitution (depending, of course, precisely how it was devised) this approach would have been more difficult to pursue. Some of the arrangements that will have to alter to accommodate Brexit - for instance, the relationship between the UK and devolved levels of government, and the position of Northern Ireland within the UK - would probably be provided for in a UK written constitution, if it existed. Their implementation could not have been forced through from the centre, despite pronounced misgivings in various parts of the UK. Consequently, those devising the referendum would have needed to give more thought in advance to what was required; and to the need to establish a broader consensus for those changes.
\end{abstract}

Slightly removed from but connected to Brexit is the question of protective mechanisms. Under written constitutions, core principles and arrangements are protected by heightened amendment procedures and hard judicial enforcement. The traditional 
view of the UK constitution has been that it does not need such mechanisms, which are anyway undemocratic in nature. Those espousing this perspective have argued that the security of the system comes from other sources. In particular, they highlight the existence of informal codes of behaviour that ensure politicians behave in ways that are constitutionally appropriate; and the first-past-the-post system used for parliamentary elections, which creates an incentive for parties to gravitate towards the centre ground. The effectiveness of these safeguards seems doubtful at present. The two main parties in Parliament have lately shifted towards the extremes; and pronounced disagreement is developing about proper constitutional conduct in crucial areas such as the relationship between the executive and Parliament. The firmer regulation that a written constitution might provide is needed. Whether and how it can be obtained are unclear.

BD: I would accept that recent events have exposed a lack of certainty in the UK's constitution, but I would not necessarily characterise that as a weakness. Nor do I think that a piecemeal approach to constitutional reform makes it casual rather than considered. Short Bills on a small number of constitutional issues are likely to receive more detailed scrutiny than large Bills with clauses that are just too numerous for exhaustive parliamentary debate.

What the vote for Brexit showed was not so much the need for constitutional changes as the need for referendums to place clear choices before the electorate. When the Scots voted in their 2014 referendum on independence, they had a definite blueprint for what independence would look like: in 2013 the Scottish government published a 650-page book explaining its vision. Likewise, when the Irish voted in 2018 in favour of deleting the Eighth Amendment from their Constitution (thereby abolishing the ban on abortion), they knew what the new provisions on abortion were likely to be because the government had indicated what it was going to table for discussion in the Irish Parliament.

In 2016, when Brits voted in the Brexit referendum, they had no notion of what a vote to leave the EU would actually mean. Mrs May's aphorism that 'Brexit means Brexit' had a simplistic attractiveness to it, but it glossed over the huge differences of opinion as to what kind of Brexit would be in the UK's best interests. It reminds me of the referendum in Australia in 1999, when the people were asked whether they wanted to abolish the monarchy and make their country a republic with a President at its head: more than 60 per cent voted to maintain the status quo, largely (it seems) because those in favour of a republic disagreed bitterly on how a President should be chosen.

We do not have to wait for a written constitution in order to amend the law on referendums in the UK. Such a reform should also make it clear that referendum results are merely advisory, not mandatory. If the government fails to follow the advice of the people, the electorate can show its disapproval in the next general election.

Yes, informal codes of behaviour and the current voting system are not satisfactory ways of achieving good governance in the UK, but again the answer lies in reform, not in complete reconstruction. Parliament does occasionally restrict itself from doing certain things in the future - as an example, the Human Rights Act 1998 effectively compels Parliament to comply with the European Convention on Human Rights unless it explicitly votes not to do so. Further self-imposed restraints are imaginable and should be campaigned for. But not by developing a wholly new constitution. 
AB: If we are relying on regular Acts of Parliament to uphold rules, we are dependent upon the government of the day not seeking to amend or repeal them as it could any other form of legislation. It is true that Parliament, via the Human Rights Act 1998, has limited the doctrine of implied repeal. But it is also true that a government could repeal the Human Rights Act using express terms on simple majority votes. I would certainly not exclude the possibility of a government setting out to do so in the near future - indeed, it has long been part of the agenda of groups that are now fully in the political ascendant. In other words, we are reliant on the self-restraint of the executive and groups in Parliament to a greater extent than is comfortable. The main body that takes upon itself a role of constitutional guardianship is the House of Lords. But it - for good reason feels restrained in the extent to which it can impose itself, and its powers are legally limited also, under the Parliament Acts 1911/1949.

I do not think it would be possible by legislative or other means to guarantee that governments avoid referendum questions that are open-ended, since they are often held for reasons of political expediency, and political expediency may dictate an open-ended question. However, if the outcome of a referendum could entail substantial constitutional change, then, were that change subject to heightened amendment procedures, then some kind of check would be in place. A vague referendum question could not be a basis for major constitutional change without some kind of requirement for a higher level of consensus to that which follows.

For evidence of casual constitutional change leading to problems, I would draw attention to the Fixed-term Parliaments Act 2011, which has created confusion about one of the most fundamental features of our democratic system: how the House of Commons, the only elected component of Parliament, can express and withdraw its confidence in the government of the day, and what happens when it does. This legislation was introduced to Parliament, on a swift timetable, as an outcome of a coalition negotiation between two parties that wanted to form a government in May 2010.

A written constitution need not be vast; and would not prevent reform from taking place. But if there are rules that we genuinely want to provide with a special constitutional status, then it is the most viable means of doing so.

BD: Your argument proves too much. If 'casual' constitutional legislation can cause problems because it is poorly drafted or incomplete, how much greater difficulty could arise from a supposedly well-considered provision in a Constitution which can be amended only by a weighted majority? Putting more care into the wording of an enactment does not insulate it against interpretative questions prompted by unforeseen circumstances. South Africa's 1996 Constitution gives everyone 'the right to have the environment protected through reasonable legislative measures ... that secure ecologically sustainable development and use of natural resources while promoting justifiable economic and social development'. How many interpretative conundrums does that throw up?

More fundamentally, how is a Constitution going to prevent a future Parliament from repealing it? This could be achieved only if the Constitution abolished the doctrine of parliamentary sovereignty and specified a new set of rules for determining what is or is not constitutional. Personally, I think it is a blessing that at present we do not need to distinguish between what is or is not constitutional: it is enough that we distinguish between what is or is not legal. 
I am not against signifying the importance of some laws by requiring their repeal to be subject to a weighted majority in Parliament - as has recently been done at the devolved level regarding proposals to change electoral law in Scotland and Wales (which now need to be approved by two-thirds of the MSPs or AMs) - but, just as you suggest could happen with the Human Rights Act, the new provisions in the Scotland Act 1998 and Government of Wales Act 2006 could still be repealed by a simple majority vote at Westminster.

At base I am against any rules being given a special constitutional status, other than the rule that Parliament is sovereign. Even with a first-past-the post electoral system, which I would certainly replace with a PR system, it is preferable to maintain the status quo rather than fixate on agreeing a set of quasi-immutable principles. Let's have Acts on human rights, equality, fairness and socio-economic justice. That's how societies thrive, not through highfalutin constitutionalism.

Finally, I am content that our judiciary continue to do a good job in holding our lawand policy-makers to account. Lord Sumption's Reith Lectures, in which he bemoans the expansion of the judicial empire, are overstated. He fails to articulate the very real constraints under which our top courts still operate, however much they appear to be free agents. I can anticipate the day when, if required, they will be prepared to declare an Act to be illegal because it is contrary to the rule of law.

\begin{abstract}
AB: That it can be relatively easy to bring about changes of a constitutional nature, without their being subject to due consideration that might improve their quality, does not necessarily mean that, if they prove problematic, they can as easily be reversed. An obvious example of a change that will be incredibly difficult to reverse is departure from the EU. Even if the UK were to decide at some point in the future that it wished to rejoin, doing so would be dependent upon the agreement of the EU and its member states. Perhaps they would be more inclined to readmit a country that could not embark upon such major constitutional courses of action at such a low threshold of approval.
\end{abstract}

While Brexit may be an exceptional example of constitutional change that is too easy to bring about but too difficult to change, there are other examples. The progressive transfer of power away from local government from the 1930s onwards came about in the supposed grand tradition of pragmatic incrementalism. The movement was in one direction. The central authorities, once they had acquired this power, were unlikely to relinquish it.

Then there is the Barnett Formula. This method of calculating changes in territorial funding allocations may have its supporters, but I am not aware of who they are. It came about in the late 1970 s as a stopgap. The person whose name is attached to it, Joel (later Lord) Barnett was not aware at the time he was creating an important component of the UK constitution; and was subsequently bemused to discover that he had. It is hard to imagine a more casual form of constitutional change. There has long been a consensus that the formula is flawed on technical and principled grounds. But it has become heavily politically entrenched, to the point that, during the 2014 Scottish independence referendum campaign, the leaders of the Conservative, Labour and Liberal Democrat parties pledged to maintain it in perpetuity. Whether that commitment will prove true, the lack of a written constitution made the introduction of a problematic funding distribution formula easier than it might otherwise have been; but it has not made it easy to dispense with and to replace with a needs-based formula. A UK written constitution 
would probably not include an actual formula in its main text. But it could well contain a statement of the principle of redistribution, the basic requirements it would address, and the process by which such a formula could be established and changed.

I agree with you that Sumption has overstated the case about judicial interference. He does so as part of a thesis that is also opposed to the idea of a written constitution for the UK. You make a better case against the written constitution than Sumption does. However, your final point, that judges might one day declare an Act of Parliament illegal because it violates the rule of law worries me. I am aware that jurists in the so-called 'common law constitutionalist' school take the view that courts might take it upon themselves to put aside the doctrine of parliamentary sovereignty in the interests of upholding core constitutional values. If they did so, they would be playing into the hands of those who subscribe to the thesis, of which Sumption is an exponent, of judicial overreach. It would be easy to caricature them as assuming a role that is beyond their proper remit. However, that you contemplate the possibility of judges setting aside an Act of Parliament in certain circumstances demonstrates that there may be circumstances in which it is proper, and indeed necessary, to do so. It is precisely the purpose of a written constitution to set out what those circumstances are. It would be better, therefore, to have a written constitution to perform this function, rather than expecting the courts, who would be politically exposed, to infer core principles on their own account.

Distinguishing matters of constitutional principle from more regular activities is not an abstract exercise, it is a means of determining who we are and what we stand for as a democratic society. It would not resolve all disagreements over ambiguities, but might provide some clearer guidance than presently exists, for instance, regarding whether the purported desire of an incoming Prime Minister to set out a new legislative agenda should take priority over the ability of Parliament to convene to discuss issues of major importance. As it stands, the constitution is often little more than a matter of opinion, with the opinion of whoever is in the position of most power prevailing.

Creating Acts of Parliament which protected certain areas of the constitution through parliamentary supermajority requirements would be a task almost as demanding as establishing a proper written constitution (which I recognise would be a challenging exercise). Why go to this trouble, if the protections themselves could be removed by simple legislative procedures? Supermajority protections can work in the devolved context precisely because the devolved legislatures are not 'sovereign' in the same way as the UK Parliament, and aspects of the basic constitutional framework within which they operate are beyond their reach. To draw attention to the effectiveness of such measures is to make the case for a written constitution, since the devolution statutes in many senses perform this function for the devolved polities. The UK Parliament should be subject to these kinds of limitations, just as its devolved counterparts are. I do not buy the argument that it is impossible to supplant parliamentary sovereignty. There are many territories across the world that were once (in theory at least) subject to the sovereignty of the UK Parliament, but that are no more, and have their own legislatures that are, with the exception of the case of New Zealand, subject to written constitutions of some kind. This outcome was achieved by various means, ranging from the violent and abrupt, to the more gradual and peaceful. The crucial requirement was that those responsible for the operation of the constitution came to accept that a new fundamental source of constitutional authority, or 'rule of recognition', applied. If it was possible elsewhere, it is possible here. 
BD: I cannot agree that a written constitution would avoid the problem of too easily taking a constitutional step and then discovering that reversing the step is very difficult. If a written constitution had been adopted in the 1980s it may have made it clear how the UK could adopt or reject future amendments to the Treaty of Rome (as Ireland's Constitution did), but I doubt if anyone would have thought to insert a provision on how the UK would be able to withdraw itself from that amended treaty. Even the EU itself had not worked out its stance on that by then. When it did do so (by drafting Article 50 in the Treaty on European Union in 1992) it clarified what the EU would require, but it left it up to member states to decide what their own constitutional requirements should be. UK lawyers knew that those requirements included the repeal of the European Communities Act 1972, but we had to await a decision by the Supreme Court before knowing whether the power to trigger the leave process was in the hands of government or Parliament. Would a written constitution have provided a quicker answer?

The Barnett formula does need to be reformed, and frankly I do not see the party leaders' 2014 pledge to maintain the current formula in perpetuity as a real obstacle to its reform. Breaking a pledge by a former party leader would be embarrassing for a new leader, but it could easily be justified by citing changed circumstances. Everyone knows that politicians are in no position to make commitments that are binding for ever. That said, I am at one with you in hoping that the method for calculating the formula should be put on a legislative (if not constitutional) basis.

We are currently in the midst of a plethora of court cases challenging the Prime Minister's decision to prorogue Parliament for a longer than usual period. While I am generally in favour of judicial activism, I am not in favour of judges trespassing into areas that are quintessentially political in nature, and a decision to put an end to a parliamentary session is one such area. Judges would be very unwise to substitute their own political intuition for that of an elected government. An Act of Parliament, on the other hand, is a product not just of the government but of the whole legislature. If an Act clearly breaches some fundamental common law principle, such as the right of access to justice, I think the Supreme Court would be duty-bound to declare that fact, thereby questioning the Act's legality.

I suspect that Parliament would then reconsider the Act, much as currently occurs when the Supreme Court issues a declaration that an Act is incompatible with European Convention rights. Supreme Court judges do not have the final say; they simply provide another hurdle which elected politicians need to surmount if they want their legitimacy as law-makers to be maintained. Ideally, the circumstances in which the Supreme Court could exercise this declaratory power should be specified in legislation, as is already the case with the Human Rights Act 1998. But a written constitution is not required - an ordinary Act will do. The Fixed-term Parliaments Act 2011, whatever one thinks of it otherwise, is a good example of Parliament imposing restraints on both the government and on itself (through requiring a two-thirds majority if there is a proposal to hold an early general election).

The attractiveness of Act-based supermajority requirements is precisely that they are not preserved in aspic, as a constitutional provision would be. The fact that they can be repealed does not mean that they cannot perform an important restraining function during the period in which they operate. Thus does the country's constitution gradually evolve and renew itself. I approve of a constitution where Parliament is sovereign but is nevertheless subject to at least temporary constraints which mean that a supermajority, or more explicit legislation, is required before certain actions can be taken. 
AB: There has been a relatively long interlude since our last exchange. During this time, two events of major constitutional significance have taken place. They will no doubt provide ammunition for both sides of the written constitution debate. The first is the 'Miller 2' Supreme Court judgment of 24 September 2019 on the (illegal) prorogation of Parliament; and the second is the calling of an early General Election for 12 December 2019.

On the Supreme Court judgment, I will say the following. It would have been better - for the constitution, for the legal system, for Parliament, for the Supreme Court, for the monarchy, and even for the Johnson government itself, if no attempt had been made to prorogue Parliament in the first place. Everybody lost. The Supreme Court found itself in a very difficult position - being the only barrier to a clear abuse of executive power, but having to make a decision that would inevitably be controversial. Whether or not the conclusion that was reached was correct in law I am not qualified to decide. But the reason the court found itself in this dilemma was because the traditional fallback position of our unwritten constitution - that people in positions of authority will be 'good chaps' and behave themselves - failed. One response to this episode could be simply to place the prorogation power on a statutory basis and perhaps provide for parliamentary approval. But legislating for the last abuse will not necessarily protect us against the next one. It was hard to predict that the government would attempt this particular wheeze; and the present administration or a future one may surprise us again in future with the use of the prerogative or other powers for malign ends. A more comprehensive codification of executive powers, including those exercised by the monarch pertaining to the relationship with Parliament, which makes the role of the courts more secure, is appropriate. And it might deter this or another Prime Minister from gaming the system in the way that was recently attempted. As usual, nothing is guaranteed, but this experience suggests we should now plan to prevent problems, rather than rely on an increasingly exposed judiciary to step in.

On the early General Election, some might see the bypassing of the Fixed-term Parliaments Act 2011 as a tribute to the divine flexibility of the unwritten constitution. But this flexibility was the source of the problem. The 2011 Act served the political convenience of the leaderships of two parties to the Coalition government that introduced the legislation. It was taken through Parliament with excessive haste and without sufficient consultation. Warnings were issued about defects in the Bill, but not properly heeded. If the UK had a written constitution (even the minimalist text I advocate as the most sensible initial option), basic rules pertaining to the length of Parliaments and the holding of elections would certainly be included within it. Establishing - and changing - such rules would have to be a more inclusive process, requiring closer consideration and wider approval. Any problems identified in a proposed system and the way it links to other aspects of the constitution would have to be taken into account in a way they were not in 2011. Not proceeding in this way, and preferring the use of the fabled incremental approach, led to an Act with multiple flaws. It failed to prevent an unnecessary early General Election in 2017; it created uncertainty about the rules governing confidence and the removal and installation of prime ministers; and its ultimate malfunction came when MPs chose to bypass it altogether. That Parliament is able readily to repeal constitutional legislation is not a strength. It is the source of problems, since the 'sovereignty' of the legislature enables the hasty enactment of badly conceived constitutional measures. It may well be that the Fixed-term Parliaments Act will 
be replaced in the near future. Are there any guarantees that whatever takes its place will not also be undermined by adherence to narrow interests and political imperatives?

BD: It is strange how something can appear so unfortunate to one person and yet so fortunate to another.

On the prorogation case, surely the same question could have reached the Supreme Court even if we had a written Constitution, for would such a Constitution inevitably pin down the precise circumstances in which a Parliament can be prorogued? After all, a prorogation simply marks the ending of one parliamentary session and the start of another one. Some discretion will almost inevitably have to be granted to the government of the day - or even to the Parliament of the day - to decide when that caesura should fall. All sorts of dubious reasons could be given for such a decision, and it would take a court to rule on which reasons were valid or not. You should not say that you are not qualified to say whether the Supreme Court made the correct decision or not. What matters more is whether you agree with the ratio decidendi of the case - if you don't object to reverting to that much maligned concept. I think the court was right to say that prorogation is lawful only if it is justified on reasonable grounds, just as most other decisions taken by public bodies are valid only if they are a reasonably justifiable exercise of the power which is being exercised. I see the decision as one more step on the path to a constitution in which the doctrine of separation of powers plays a full and proper role. That said, I would not be averse to a codification of all prerogative powers and an express legislative statement as to the basis on which their exercise can legitimately be challenged.

The Supreme Court's decision was also remarkable in other ways. That such a momentous step was taken unanimously and with relative brevity speaks volumes for the persuasiveness of the President, Lady Hale. Given that the Deputy President, Lord Reed, had been one of the three dissenters in the first Miller case, where he held that the government did have the power to trigger Article 50 of the Treaty on European Union, I had imagined that he and at least one or two other 'conservative' judges, such as Lord Carnwath or Lord Lloyd-Jones, would find that the Prime Minister was within his rights to prorogue in the way that he did. The fact that the prorogation was in any event ineffective in preventing Parliament from passing a law to stop the country leaving the EU on 31 October with 'no deal' - the European Union (Withdrawal) (No 2) Act 2019 did, I thought, considerably undermine Gina Miller's case. My hunch was that the Supreme Court would say that it had the power to control the use of the prerogative power to prorogue, but that on the facts of this case the exercise of the power had been within acceptable bounds. I was pleasantly surprised by the clarity of the eventual outcome, but I still wonder what the court would have said if Boris Johnson had been more honest and open with the court in revealing his reasons for deciding to lengthen the normal period for a prorogation: would the court still have held that his political reasons were unjustifiable and, if so, what objective criteria would they have used to make their assessment?

On the evasion of the Fixed-term Parliaments Act 2011, I see the Early Parliamentary General Election Act 2019 as an ingenious example of the doctrine of parliamentary sovereignty at work. Yes, the 2011 Act was not properly thought through at the time and perhaps should be repealed (as a Private Members' Bill in the House of Lords is trying to do at the moment), but had the provisions for fixed-term Parliaments been included as part of a written Constitution we would have to go through all sorts of constitutional 
contortions to allow it to be disregarded at a time when it was patently necessary to do so. The saga should remind us that politics is the art of the possible, and that the more the constitution tries to restrict the artistry of politicians the less likely it is be effective in facilitating a healthy democracy.

I am curious to know how you think the question of a second independence referendum in Scotland is likely to be resolved. If the Scottish National Party (SNP) wins anything like the number of seats there as it did in 2015 (56 out of 59), would it be 'constitutional' for the UK government and/or Parliament to continue to refuse the Scottish government the right to hold another people's vote on independence? How can the SNP obtain that right except through political persuasion? And if you think a written Constitution could easily make provision for such eventualities as regards Scotland, Wales or Northern Ireland, what would happen if an English region - let's say Yorkshire suddenly decided it wanted to break away too?

AB: I doubt that a written constitution would stipulate that the government could prorogue Parliament unilaterally if a majority in the Commons were opposed to this course of action. It could thereby close off the potential for abuse.

On the 2019 General Election, perhaps this early poll was needed, perhaps it was not. The point is that the 2011 Act was readily discarded, and by legislation the drafting of which raises some very problematic and complex issues, which I expect shortly to be subject to expert scrutiny. I doubt a written constitution would make an early election impossible. But it is interesting to ask, what if the 2017-2019 House of Commons had known that it had to continue operating until 2022? Would the deadlock have continued throughout this period? Or would political leaders have been forced to behave in a more conciliatory fashion?

As regards the position with referendums on departure from the UK, a written constitution could, if deemed appropriate, establish the principle that a territory can leave the UK, the means by which it could do so (presumably a referendum), the requirements for the triggering of that referendum (such as a vote in the devolved legislature) and how frequently such referendums could be held. This position would be an improvement on where we are now. Creating a right of secession would probably be unique internationally, but we already have it for Northern Ireland, and the Scottish independence referendum suggests that it exists in some vaguely defined sense for Scotland. Whether it should have been implicitly conceded in the way it was by David Cameron in 2011 is potentially a subject of debate - but he was able to do so, because of the nature of our constitution. Flexibility often means flexibility for whoever holds office at UK level.

Would this principle apply to Yorkshire (or Cornwall etc)? A written constitution could provide for the establishment of devolved units within England, if there was demand within those areas, but need not establish them immediately. If they were formed, they could acquire the same rights of secession as the other parts of the UK, in the (presently unlikely) event they wished to use them. It is entirely possible for this kind of process of decentralisation to take place within the context of a written constitution, which could mandate for flexibility.

I would query whether the way in which the UK has approached territorial issues reveals its 'unwritten' constitution as the model for success that is sometimes claimed. It has demonstrated the capacity both to resist change for an inordinate period, and to act in haste in ways that create problems for the future. Lord Byron noticed this tendency 
long ago. As he put it in his maiden speech in the House of Lords on 27 February 1812 (objecting to the government plan to introduce the death penalty for 'Luddite' framebreakers), when faced with desirable measures, Parliament could 'hesitate ... deliberate for years ... temporise and tamper with the minds of men'. But less well-advised Bills could 'be passed offhand, without a thought of the consequences'. Our constitution invites this kind of abuse.

BD: If the kind of written constitution you envisage is going to provide the degree of flexibility you talk about, I cannot see that we would then be in a very different position from the one we are in at present. Byron, predictably, over-dramatises the situation: 'act in haste, repent at leisure' is a maxim for every level of governance, but we should not let it be an excuse for inaction.

I maintain that, when it comes to constitutional developments, evolution is better than revolution. If a written constitution is to be more than just a consolidation of existing statutory provisions, coupled with a bunch of new provisions that will supplement the others and create an overall constitutional code, it is going to have to adopt firm positions on a range of issues that at present are shrouded in the garb of constitutional conventions. If it were to re-enact a provision such as we find in section 28(8) of the Scotland Act 1998, which says 'it is recognised that the Parliament of the United Kingdom will not normally legislate with regard to devolved matters without the consent of the Scottish Parliament', the constitution would surely have to indicate whether judges are allowed to decide what 'normally' means. At present, as we know from the first Miller decision in 2017, judges regard that provision as asserting only a political convention not a legal rule, so they treat it as something they have no jurisdiction to deal with. If the written constitution were to alter that present position it would need to indicate what principles judges should use when interpreting the term 'normally'. Would traditional judicial review principles apply, even though what is being reviewed is a decision to enact primary legislation?

The current position regarding the status of Northern Ireland is different because what might be challenged is not a decision to enact (or not enact) primary legislation, but a decision to hold (or not hold) a border poll. The Northern Ireland Act 1998 provides (in Schedule 1, paragraph 2) that a border poll must be held if at any time it appears likely to [the Secretary of State for Northern Ireland] that a majority of those voting would express a wish that Northern Ireland should cease to be part of the United Kingdom and form part of a united Ireland'. I would suggest that in a few years' time a court challenge will be raised against the Secretary of State's refusal to decide to hold a poll. It will then be up to the courts to rule on whether the Secretary of State's assessment of the 'likely' outcome of a poll was 'Wednesbury unreasonable'. They are bound to be reluctant to second-guess the Secretary of State's assessment, which will have been deeply influenced by political considerations. Some years ago, the courts refused to strike down a decision by the then Secretary of State, Mo Mowlam, that the IRA's ceasefire was still holding, notwithstanding considerable evidence that it had already been breached ( $R e$ Williamson's Application [2000] NI 281).

You might retaliate by saying that a written constitution cannot be expected to cover all bases, but surely the main point of writing it is to make the constitution less uncertain in its application. I think that's largely a chimera. 
AB: I agree that a written constitution should not be constructed in such a way as to allow a court to determine what 'normally' means. But neither should it be left to a government with a majority in the Commons, potentially with little political support in devolved territories, to make this decision. I do not believe that the UK is uniquely incapable of collectively arriving at a definition and/or mechanism by which a more consensual conclusion could be reached on these matters, which would not necessarily always require the courts to become involved.

Conventions are unavoidably a part of any constitution, written or unwritten. At the moment, some of our conventions have come into question, along with the general idea that we can rely on politicians of different affiliations to abide by an implicit code of good behaviour. Recent events have cast doubt upon some of the most basic assumptions surrounding our system, such as (as I mentioned previously) how to discern whether or not a government possesses the confidence of the House of Commons, and what should happen if it has lost it; and the idea that politicians will take steps to avoid drawing the monarch into political controversy. The failure to give due consideration to the impact of UK departure from the EU on the Northern Ireland peace process, both before and after the 2016 referendum, is another example of politicians not accepting that they are constrained by certain obligations. The failure of our constitution to prevent or resolve this particular issue has meant that outside forces, namely the EU27, have had to impose a solution upon us - the implications of which are difficult to predict in advance. It would be better if we were able to devise rules of our own and stick to them than have to have others carry out the task for us.

I am not attributing the whole of the blame for these problems to any one individual or party - there are systemic problems at work here.

I would question the evolution-revolution dichotomy that is sometimes advanced to distinguish the UK constitution from that of others. There are plenty of instances of abrupt change in the past of the UK and its precursors and successor states. In 1973, for instance, a Parliament that until not long beforehand had claimed 'sovereignty' over a large portion of the population of the world, arguably subordinated this sovereignty to that of European institutions. The constitutional changes of 1997-2005 - including devolution, the Human Rights Act 1998, the removal of most hereditary peers from the House of Lords (1999), the creation of the Supreme Court and the Judicial Appointments Commission (under the Constitutional Reform Act 2005), the Freedom of Information Act 2000, the Political Parties, Elections and Referendums Act 2000 amounted to a major systemic overhaul that goes beyond 'evolutionary', but might be better provided for within the context of a written constitution.

Perhaps another revolution is underway as we leave the EU. As Vernon Bogdanor has argued, it is as though we are moving away from a system that had some of the features of a written constitution, provided by European law. This fundamental transition is taking place after a General Election. The party that won it did so on a manifesto containing various statements that it could claim provide it with a mandate to circumscribe the power of the courts, dilute human rights protection, and various other changes. Under the UK constitution, having a supposed mandate under the first-past-the-post system and a majority in the House of Commons can be enough to bring about changes that would require adherence to more demanding and consensual amendment procedures under other systems. None of those systems are perfect, and ours has many strengths. Unfortunately, we are now witnessing some of its weaknesses, which may show why it 
would be good if we already had a written constitution in place. In a strange way, we may be witnessing the type of scenario Lord Hailsham wished to avert when, in 1976, he called for a written constitution to protect against elective dictatorship. However, the chances of securing a written constitution - or at least one worthy of the name - are now remote.

BD: I remain unconvinced that some sort of special constitutional provision should have been envisaged in relation to the Belfast (Good Friday) Agreement for the day when the UK might want to leave the EU. Frankly, I think that Brexit is perfectly compatible with the maintenance of the Agreement and that the alleged negative consequences have been greatly over-hyped, not least in the field of human rights. It is difficult to imagine what constitutional provision could have been devised to prevent the complexities of Brexit for Northern Ireland short of an outright exemption for Northern Ireland from any UK referendum on whether Brexit should happen or not. That would have amounted to a much more obvious breach (in spirt at least) of the Belfast (Good Friday) Agreement than Brexit itself is claimed to be.

The truth is that the peace process in Northern Ireland can and should continue notwithstanding Brexit. A much more significant threat to the process has been the combined failure of the Democratic Unionist Party (DUP) and Sinn Féin to agree a way in which the Assembly and Executive can be restored in Belfast: they collapsed, of course, not because of Brexit but because of Sinn Féin's exasperation at the way the DUP was supposedly treating the nationalist community with disrespect and at how Arlene Foster, the DUP's leader, was handling a monumental financial scandal concerning expenditure on a 'renewable heat incentive' scheme.

Ironically, the exit deal which Boris Johnson secured from the EU27, while portrayed in unionist circles as 'placing a border down the Irish Sea', has the potential for being economically advantageous for Northern Ireland because it allows Northern Ireland to be part of the EU customs union and, simultaneously, of the UK's own internal customs union. There may be some extra bureaucracy at ports and airports, and we still do not know how Northern Ireland will feature in the future trade deal between the EU and the UK, but Northern Ireland might well continue to benefit from the best of both worlds.

The constitutional changes made between 1997 and 2005 were possible only because the then Labour government had a huge majority in the House of Commons. Maybe that period was more illustrative of Hailsham's elective dictatorship? Even so, I don't see the changes as revolutionary. They left the doctrine of parliamentary sovereignty fully intact, the House of Lords has continued in being as a completely unelected body with legislative powers and the Supreme Court is virtually indistinguishable from the Appellate Committee of the House of Lords, notwithstanding that the judges now have their own separate building. Devolution was a huge step, yes, but in hindsight it may be seen as the first step on the road to the break-up of the UK. I maintain that what would help to prevent that calamity would be a Constitutional Reform Act that formally federalises the UK, thereby confirming the purpose of the union and setting out clearer dividing lines between the powers of the constitutive states and the federal government.

I welcome the new government's commitment to establishing a Commission on the Constitution, Democracy and Rights. It should stimulate debate and force everyone to think carefully about what really makes for a free and fair society. Yes, there are risks that recommendations may emerge from it which you and I would disagree with, but I believe 
that there are sufficient checks and balances in our unwritten constitution, and enough common sense in the electorate as well as in Parliament, to ensure that hare-brained ideas do not ultimately become enshrined in law or policy. I am happy to agree with you that enactment of a written constitution is, in my view happily, a very unlikely outcome. 
